\title{
Ritka kompozit lymphoma: köpenysejtes lymphoma és follicularis lymphoma
}

\section{A rare composite lymphoma: mantle cell lymphoma and follicular lymphoma}

\author{
Timár Botond ${ }^{\circledR}$ \\ Semmelweis Egyetem, I. sz. Patológiai és Kísérleti Rákkutató Intézet, Budapest
}

(Beérkezett: 2020. június 22.; elfogadva: 2020. szeptember 8.)

\begin{abstract}
A 83 éves beteg anamnézisében komoly betegség nem szerepel. Felvételekor laborparaméterei normálisak voltak. Ambulancián 3-4 hete növekvő nyaki nyirokcsomómegnagyobbodás miatt jelentkezett, amely sebészi úton eltávolításra került. A feldolgozott $27 \times 22 \times 14 \mathrm{~mm}$-es nyirokcsomóban follicularis szerveződésű folyamat képe látható. A follicularis szerkezetet a CD21 immunreakcióval feltárt prominens follicularis dendriticus sejtes (FDC) hálózat is alátámasztja ( $1 \mathrm{~A}$. ábra), amely több helyen öszszetett noduláris szerveződést és szokatlan FDC-mentes köpenyzónagyürüt mutat. A folliculusoknak jól megtartott, még polarizáltnak is imponáló köpenyzónájuk van,
\end{abstract}

de a centrum germinatívumok egyértelmúen neoplasticusak, polarizáltságuk megszűnt, tingibilis macrophagokat nem tartalmaztak. A folliculusok dominálóan centrocyter sejtekből állnak, kevés centroblasttal ( 10-15/nagy nagyítású látótér) (1B. ábra). Az immunreakciók alapján a nyirokcsomó sejtjei homogén CD20-expressziót mutatnak, kevés reaktív CD3-pozitív T-sejttel (ábra nélkül). A folliculusok centrális sejtjei CD10-, Bcl-2- (1C., ill. $1 D$. ábra) és Bcl-6-pozitívak, CD5-negatívak, és az interfollicularis komponens is CD10-zel jelölődik. Ezzel ellentétben a folliculusoktól és az interfollicularis zónától is élesen elhatárolódva a köpenyzóna sejtjei CD10-negatívak,

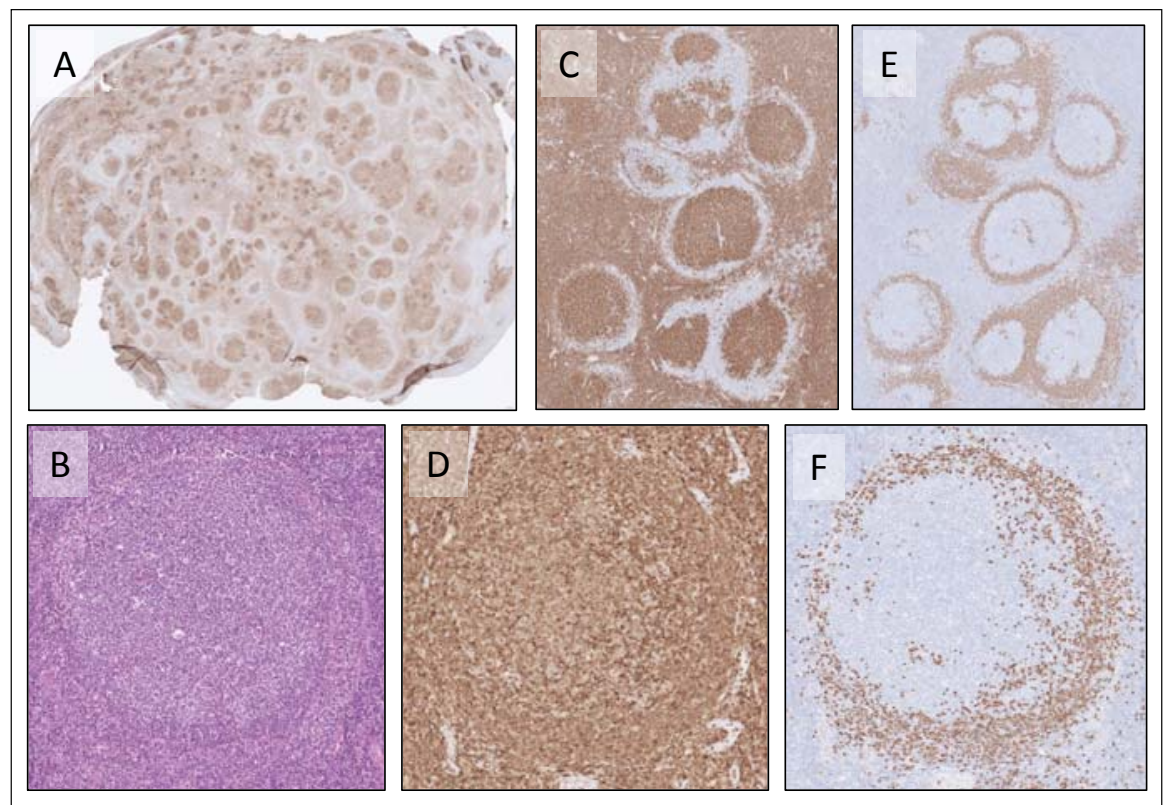

1. ábra. A nyirokcsomó szövettani képe és immunhisztokémiai profilja a feltüntetett eredeti nagyításokkal. A - CD21 (6x), B - H\&E (100×), C - CD10 (23×), D - Bcl-2 (100x), E - CyclinD1 (23x), F - CyclinD1 (100x)

\footnotetext{
@ Levelezési cím: Dr. Timár Botond, Semmelweis Egyetem, I. sz. Patológiai és Kísérleti Rákkutató Intézet, 1085 Budapest, Üllői út 26.; E-mail: timar.botond@med.semmelweis-univ.hu
} 
Bcl-6-negatívak, halvány CD5-expresszióval és intenzív CyclinD1-pozitivitással (1E. és $1 F$. ábra). Fluoreszcencia in situ hibridizációval (FISH) a neoplasticus folliculusok területén a $\mathrm{t}(14 ; 18)$, a köpenyzóna területén pedig a $\mathrm{t}(11 ; 14)$ transzlokáció volt kimutatható. A nyirokcsomószuszpenzión elvégzett áramlás-citometriai vizsgálat során a $\mathrm{CD} 10+$ komponens lambda klonálisnak, a CD5+ komponens kappa klonálisnak bizonyult, amelyek így klonálisan független entitásoknak tekinthetők. A morfológia és a fenotípus alapján a látottakat follicularis lymphoma és köpenysejtes lymphoma komponensü kompozit lymphomának diagnosztizáltuk. A diagnózis idején egyéb nyirokcsomó-érintettség nem volt igazolható, de a két héttel a diagnózist követő csontbiopsziás stagingmintában csak a CD5+ köpenysejtes lymphoma volt jelen. A kompozit lymphoma definíció szerint kettő vagy annál több lymphoma entitás együttes előfordulását jelenti ugyanazon anatómiai struktúrában (egyazon nyirokcsomó, vagy extranodális szerv), amelyek lehetnek klonálisan kapcsolt vagy egymástól klonálisan független entitások is [1]. Az irodalmi adatok alapján esetünk extrém ritkaság, mivel egy 2014-es irodalmi áttekintésig összesen csak 6-6 olyan esetet írtak le [2], és azóta is csak két esetismertetés született [3], ahol vagy köpenysejtes lymphoma és follicularis lymphoma vagy in situ köpenysejtes neoplasia ("in situ mantle cell neoplasia" - ISMCN) és follicularis lymphoma együttes előfordulása volt megfigyelhető nodális vagy extranodális megjelenéssel. Az in situ köpenysejtes neoplasiák kifejlett köpenysejtes lymphomába való transzformációjának aránya nem ismert, de az ISMCN diagnózisához mindenképpen szükséges a szisztémás érintettség kizárása. Jelen esetben a köpenysejtes folyamat „in situ” jellegét, a köpenyzónára korlátozott nyirokcsomó-érintettség ellenére is csak a stagingvizsgálat zárta ki. Az eset tanulsága, hogy az ilyen ritka, kompozit eltérések felfedéséhez a finom morfológiai megfigyelés mellett is széles immunhisztokémiai panel alkalmazása szükséges, esetenként molekuláris vizsgálatokkal kiegészítve.

Nyilatkozat: A kézirat más folyóiratban korábban nem jelent meg.

Érdekeltségek: A szerzőnek a közleményhez kapcsolódó érdekeltsége nincsen.

\section{Irodalom}

[1] Wang S, Tzankov A, Xu-Monette ZY, et al. Clonally related composite follicular lymphoma and mantle cell lymphoma with clinicopathologic features and biological implications. Hum Pathol 2013; 44: 2658-2667.

[2] Taverna J, Nair A, Yun S, Paulson S, et al. A rare presentation of in situ mantle cell lymphoma and follicular lymphoma: a case report and review of the literature. Case Rep Hematol 2014; 2014: 145129.

[3] Mari-Jimenez P, Martinez-Losada C, Centeno-Haro M, et al. A rare composite lymphoma: follicular and in situ mantle cell. Ann Hematol 2016; 95: 1351-1352.

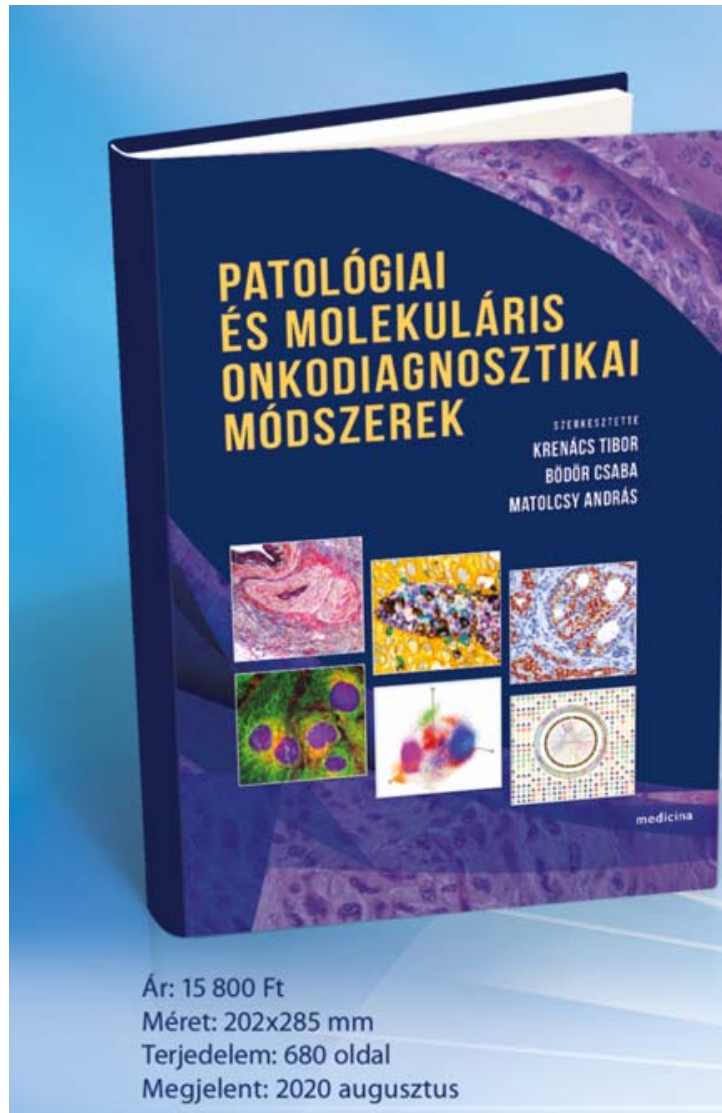

Innovatív patológiai szakkönyv, amely a témát és annak dinamikus evolúcióját a módszertan oldaláról közelíti meg.

A 35 alfejezetet magában foglaló 18 fejezet a korszerű patológiai és onkodiagnosztikai módszerek elméleti alapjainak fókuszált bemutatása és esszenciális összefüggéseinek megvilágítása mellett reprodukálható és ellenőrzött protokollokat, módszertani algoritmusokat és részletes differenciáldiagnosztikai összefoglaló táblázatokat tartalmaz, amit demonstratív példák és gazdag ábraanyag támogat.

Részletesen tárgyalja többek között a mikroszkópos módszereket klasszikustól a szuperfelbontású mikroszkópiáig, a patológiai mintaelőkészítés és -feldolgozás, az immuncito-/hisztokémia, az áramlási citometria, az in situ hibridizáció, a PCR alapú molekuláris onkológiai módszerek, az újgenerációs szekvenálás (NGS), a célzott terápiákhoz kötődő molekuláris diagnosztika, a digitális patológia, az automatizált képanalízis, a mesterséges intelligencia, a szöveti multiblokk (TMA) módszer, a képalkotó tömegspektrometria („multiplexing”), a sejttenyésztés, valamint a biostatisztika és a bioinformatika patológiai alkalmazását és jövőbeni potenciálját. Emellett bemutatja a szövetpatológiai osztályok felépítésének és működtetésének minőségügyi szabályait és elvárásait.

Hiánypótló kötet, amely a patológiában tevékenykedők mellett a társszakmák képviselőinek figyelmére is számíthat a közös cél, a kor színvonalának megfelelő diagnosztika és gyógyítás érdekében.

www.medicina-kiado.hu

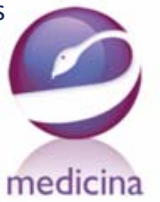

A cikk a Creative Commons Attribution 4.0 International License (https://creativecommons.org/licenses/by/4.0/) feltételei szerint publikált Open Access közlemény. (SID_1) 